\title{
Glacier tourism and climate change: effects, adaptations, and perspectives in the Alps
}

\author{
Emmanuel Salim ${ }^{1}$ (1) $\cdot$ Ludovic Ravanel $^{1,2} \cdot$ Philippe Bourdeau $^{3} \cdot$ Philip Deline $^{1}$
}

Received: 30 May 2021 / Accepted: 2 October 2021 / Published online: 6 November 2021

(c) The Author(s), under exclusive licence to Springer-Verlag GmbH Germany, part of Springer Nature 2021

\begin{abstract}
Climate change strongly affects mountain tourism activities. Glacier tourism is highly affected by the retreat of glaciers. However, research on the effects and adaptations of glacier tourism to climate change is scarce in Europe. By analysing the glacio-geomorphological literature, semi-structured interviews, and observations at six major Alpine glacier tourism sites, we aim to identify the physical processes that affect glacier tourism in the Alps and how stakeholders perceive and adapt to them. The results reveal that glacier retreat and the associated paraglacial dynamics and permafrost warming strongly affect glacier tourism. Stakeholders perceive six main issues: management, itinerary, infrastructure, attractiveness, safety, and activity. In response, they have been adapting with eight strategies: management change, technical means implementation, mitigation, diversification, access and itinerary maintenance, heritage development, planning, and implementation of transformation projects. These strategies are discussed regarding their relevance to tourism model transition to guarantee future sustainability.
\end{abstract}

Keywords Glacier tourism · Climate change · Adaptation · Transition · European Alps · Geomorphological processes

\section{Introduction}

Today, tourism is primarily affected by climate change. A literature review reveals that tourism is one of the only attributes to be affected by 10 identified climate hazards: 'warming, heatwaves, precipitation, drought, floods, fires, storms, sea-level rise and changes in natural land cover and ocean chemistry' (Mora et al. 2018. p. 1062). The United

Communicated by Juan Ignacio Lopez Moreno.

Emmanuel Salim

emmanuel.salim@univ-smb.fr

Ludovic Ravanel

ludovic.ravanel@univ-smb.fr

Philippe Bourdeau

philippe.bourdeau@univ-grenoble-alpes.fr

Philip Deline

philip.deline@univ-smb.fr

1 Univ. Savoie Mont-Blanc, CNRS, EDYTEM, 73000 Chambéry, France

2 University of Lausanne, CIRM, 1967 Bramois, Switzerland

3 Univ. Grenoble-Alpes, UMR PACTE CNRS, LabEx ITTEM, Grenoble, France
Nation World Tourism Organisation (UNWTO) et al. (2008) reported that tourism is vulnerable to increased temperature, extreme events, cryosphere reduction, and drought (i.e. climate risk). Recently, Scott (2021) acknowledged that climate risk management is one of the two challenges (along with carbon risk) that tourism will face in the next 30 years. The Intergovernmental Panel on Climate Change (IPCC; 2014) defines adaptation as a priority to cope with the effects of climate change.

In addition to studies on the global vulnerability of tourism to climate change (e.g. Scott et al. 2019), studies on different tourism niches have been conducted regarding whale watching (Lambert et al. 2010), bird watching (Kutzner 2019), or Arctic cruise tourism (Dawson et al. 2016). Winter activities have been the subject of many research studies in mountainous territories, especially concerning the effects of climate change on the ski industry and its adaptations (Gilaberte-Búrdalo et al. 2014; Joly and Ungureanu 2018; Steiger et al. 2019).

However, among other mountain tourism activities, glacier tourism is a vital summer tourism niche dramatically affected by the glacier retreat due to climate change (Wang and Zhou 2019; Welling et al. 2015). An increasing number of studies have demonstrated that glacier tourism 
is undergoing the consequences of climate change, leading to greater difficulty accessing glaciers (Stewart et al. 2016; Mourey and Ravanel 2017), more dangerous activities (Purdie et al. 2015), or loss of attractiveness of the site (Diolaiuti and Smiraglia 2010). Glaciers visited by tourists worldwide have been the subject of research concerning the effects of climate change.

Glacier tourism is of particular importance regarding summer tourism in the European Alps. For example, the Aiguille du Midi and Montenvers (France) are considered by the Savoie-Mont-Blanc Agency as the two most-visited tourist destinations in Savoy (Savoie-Mont-Blanc Tourisme 2019), and other glacier tourism sites in the Alps bring in more than one million visitors per year (Salim et al. 2021b). However, this topic regarding the European Alps remains under-investigated despite the importance of glacier tourism in its tourism development (Salim et al. 2021a). Accordingly, this paper aims to fill this geographical gap by contributing to the research on how climate change affects glacier tourism in the European Alps and how tourism operators and stakeholders adapt to these changes.

\section{Literature review}

\section{Climate change and glacier tourism worldwide}

How climate change affects glacier tourism has been increasingly studied over the last 10 years. Particularly well-studied examples are the Fox and Franz Josef glaciers in New Zealand. The area attracts around 700,000 visitors per year and has been considered the area with the most accessible glaciers in the world (Purdie 2013). However, the Fox glacier has lost $700 \mathrm{~m}$ in length and 100 to $150 \mathrm{~m}$ in thickness from 2008 to 2014 at the level of its terminal tongue (Purdie et al. 2015). This extremely rapid retreat has completely changed the possibilities for accessing the glaciers, making hiking on the ice increasingly difficult and sometimes dangerous (Purdie et al. 2015; Stewart et al. 2016). In New Zealand Aoraki-Mont Cook National Park, the Tasman glacier has also retreated rapidly, allowing a proglacial lake to develop whose area almost tripled from 1990 to 2018 (Purdie et al. 2020). Touristic activities, such as boat tours, have been set up around it (Stewart et al. 2016).

Another example is the Athabasca glacier in Canada, which has lost almost $50 \%$ of its thickness and $1.5 \mathrm{~km}$ of its length since the end (mid-nineteenth century) of the Little Ice Age (Groulx et al. 2016). This evolution has increased the difficulty to access it for its one million annual visitors (Lemieux et al. 2018).

The situation is similar in Norway, where the glacier retreat led to a drop in visitors (Furunes and Mykletun 2012) or difficulties in summer skiing (Demiroglu et al. 2018). The retreat of the Icelandic glaciers raises similar issues. Access is increasingly complex, and the hazards are more significant. Moreover, the quality of the guided tours has degraded, and some attractions and ice caves have disappeared prematurely (Welling and Abegg 2019). Beyond these issues, Wang and Zhou (2019) pointed out the effects of climate change on glacier sites in terms of aesthetic, economic and cultural loss.

Climate change also threatens mountaineering routes and hut access in the French Mont Blanc massif (Mourey and Ravanel 2017; Mourey et al. 2019a, b). Climate change has reduced the aesthetic value of the Forni glacier in Italy (Garavaglia et al. 2012), modified access to the normal Everest route (Watson and King 2018), and led to the vanishing of touristic glaciers, such as the Chacaltaya glacier in Bolivia (Kaenzig et al. 2016).

\section{Adaptation to climate change}

These different effects lead to the question of adapting to climate change. The IPCC (2014) defines adaptation as the processes involved in adjusting to the current and future effects of climate change. Three main types of adaptation can be identified: coping, incremental, and transformative (Fedele et al. 2019).

Coping (or reactive) strategies do not lead to profound changes in the system. It is usually implemented to resist the effects of climate change and can be considered a 'business as usual' strategy (Kates et al. 2012). In other words, coping strategies are mainly reactive and are implemented when the effects are not severe, the elements of the system do not have the opportunity to respond in another way, or the need for changes is not recognised (Fedele et al. 2019). Examples of coping strategies in glacier tourism are covering the glacier surface with white covers to limit shrinkage or constantly renovating a trail to access a glacier (Salim et al. 2021a).

Incremental adaptation strategies provide the opportunity to continue the threatened activity by implementing minor changes. Such strategies aim to be more anticipatory than coping strategies (Fedele et al. 2019). However, this strategy provides limited changes that can sometimes increase the vulnerability of the system. For example, as access to the Fox and Franz Josef glaciers became more difficult and dangerous (Purdie et al. 2015), operators substituted walking with helicopter-assisted hikes. If they can continue to operate, they become more vulnerable, as the price has increased fivefold (Salim 2020). Moreover, this now fuel-dependent activity is indexed on energy costs (Espiner et al. 2017).

The third type of adaptation is the transformative strategy, which aims to transform the system from its vulnerabilities and move it out of an unsustainable trajectory (Fedele et al. 2019). Transformative adaptation can be implemented alone or with a series of incremental strategies (Kates et al. 2012). 


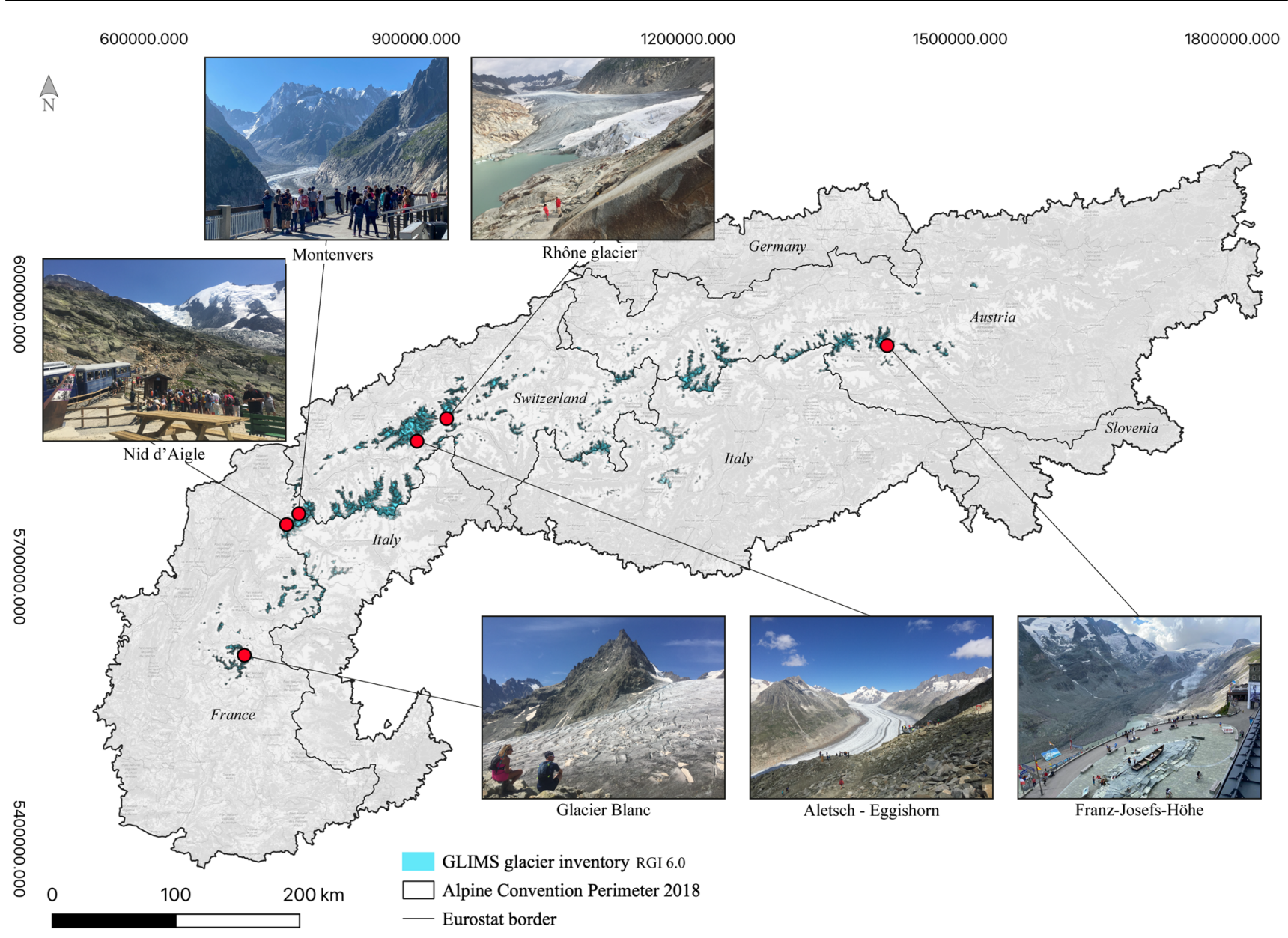

Fig. 1 Location of the six selected sites in the European Alps (see Appendix 1 for each site description)

Transformative adaptation result in a new system order (Adger et al. 2011). The shift from ski tourism to sport tourism activities at Chacaltaya glacier by developing an altitudinal training centre (Kaenzig et al. 2016) is a transformative strategy.

Considering the lack of information about the current situation of glacier tourism in the Alps and because we hypothesise that the physical effects of climate change in high mountains would make this form of tourism very vulnerable, this paper aims to answer three research questions:

i) What processes related to climate change affect Alpine glacier tourism?

ii) Are stakeholders aware of these processes?

iii) How do they adapt to the consequences of climate change?

\section{Material and methods}

Three methodological steps were implemented to answer these questions. First, we selected Alpine glacier tourism sites. Second, we conducted a literature review on the glacio-geomorphological processes for each selected site. Third, we conducted qualitative investigations combining on-site observations and semi-structured interviews.

\section{Site selection}

Out of the 73 Alpine glacier tourism sites identified by Salim et al. (2021b), six were selected across these 
geographical areas: Écrins and Mont Blanc massifs (France; $N=3$ ), Valais (Switzerland; $N=2$ ), and Höhe Tauern massif (Austria; $N=1$ ) (Fig. 1). The sites were selected according to the following criteria: (i) modest altitude $(<3000 \mathrm{~m})$; (ii) importance in terms of the number of visitors and reputation; and (iii) the largest tourist glacier in each country. For ease of reading and to limit the length of the paper, the six selected sites are described and mapped in detail in Appendix 1.

(i) Franz-Josefs-Höhe is the main viewpoint on the Pasterze glacier, the largest Austrian glacier. The site represents a stopover on the Grossglockner toll tourist road, which approximately 800,000 people visited in $2019 .{ }^{1}$ In the heart of the Höhe Tauern National Park, this site offers different viewpoints on the glacier, exhibitions on the history of the site and glacier, hikes to the glacier front, and glacier hikes accompanied by a guide from the National Park.

(ii) Rhône Glacier (Switzerland) is located along the road leading to the Furka Pass. This site allows access in less than $10 \mathrm{~min}$ along flat paths to the glacier to the ice cave dug each year since 1870 .

(iii) Eggishorn (Switzerland) is a viewpoint accessible by cable car that allows visitors to observe the tongue of the Aletsch Glacier, the largest glacier in the Alps $(22 \mathrm{~km})$. It has been visited by an average of 178,000 people during summer per year since $2008 .^{2}$ Beyond the viewpoint, the site offers a themed trail, restaurant, and several hikes along the left lateral moraine. The Swiss association ProNatura also offers glacier tours and open-air lectures on landscape interpretation.

(iv) Montenvers-Mer-de-Glace provides access to the largest French glacier via a cog railway. This site is visited by more than 400,000 people each year (Salim and Ravanel 2020). It offers the opportunity to visit an ice cave and several restaurants and take numerous hikes on and around the glacier.

(v) Nid d'Aigle (France) is accessible by the Mont Blanc Tramway, another cog railway. Visited by about 70,000 people per year during summer, ${ }^{3}$ this site offers a view of the Bionnassay glacier. It is also the starting point for the normal route to the Mont Blanc (4809 m a.s.1.).

(vi) Glacier Blanc Valley (France) is the most frequented tourist area of Écrins National Park. Many hikes are possible from this starting point, with a view of Gla-

\footnotetext{
${ }^{1}$ Unpublished data provided by the Grossglockner Road company.

${ }^{2}$ Unpublished data provided by the Aletsch Arena company.

${ }^{3}$ Unpublished data provided by the Mont-Blanc company.
}

cier Blanc, the largest glacier in the massif. The Pré de Madame Carle is the departure point for hikes to two mountain huts, the Glacier Blanc and the Écrins huts. They both allow accessing several mountaineering routes, including the Dôme de Neige des Écrins (4015 m a.s.l.), one of the most accessible 4000-m peaks in the Alps.

\section{Literature review}

A glacio-geomorphological literature review was conducted to understand the processes affecting glacier tourist sites. The research was conducted using Google Scholar with keywords (name of the glacier, site, and mountain range) for each site. All titles were checked to select articles that deal with at least one glacio-geomorphological process close to the selected tourist sites during the last 20 years. Selected articles were included in a database for qualitative and quantitative analyses. This review comprises 73 articles published between 2007 and 2020 .

\section{Semi-structured interviews}

Twenty-five semi-structured interviews were conducted with key stakeholders: public operators (city council, national parks, and tourist office; $N=7$ ), infrastructure managers (access operators, hut keepers, and ice cave managers; $N=9)$, and entrepreneurs, such as mountain guides $(N=9)$. The interviewees were selected using a purposive sampling method (Patton 2002). The number of interviews reflects the number of each type of stakeholder present at the selected site.

The interview guide varied according to the specificities of each site. However, the common topics were as follows: (i) place of the interviewee in the tourist destination, (ii) importance of the studied site in the tourist destination, (iii) effects of climate change, (iv) implemented adaptations, and (v) effects of adaptation strategies and vision for the future. The interviews were conducted in four different periods: November 2013 to March 2014 ${ }^{4}$ (3), March to April 2017 (7), September to November 2019 (7), and 2020 (8). All of them took place within the tourist destination, except for three interviews in the summer of 2020, which were conducted using video conferencing due to the coronavirus disease 2019 (COVID-19). All interviews were recorded with the participants' agreement and were transcribed for analysis using MAXQDA (Saillard 2011). The interviews lasted between 1 and $2 \mathrm{~h}$.

\footnotetext{
${ }^{4}$ Those interviews have been conducted for the purpose of Bourdeau's (2014) study and were supported by the CNRS-Zone-AtelierAlpes and the Centre d'Oralité Alpine.
} 
Table 1 Main glacial parameters measured for each glacier site

\begin{tabular}{|c|c|c|c|c|c|}
\hline Site & Glacier & $\begin{array}{l}\text { Glacier front } \\
\text { altitude (2021) }\end{array}$ & $\begin{array}{l}\text { Glacier length change } \\
\text { (measured period) }\end{array}$ & $\begin{array}{l}\text { Glacier thickness change } \\
\text { (measured period) }\end{array}$ & $\begin{array}{l}\text { Glacier velocity change } \\
\text { (measured period) }\end{array}$ \\
\hline Montenvers & Mer de Glace & $1550 \mathrm{~m}$ & -1122 m (1950-2019) & $-175 \mathrm{~m}(1900-2019)^{1}$ & $-55 \mathrm{~m} \cdot \mathrm{a}^{-1}(1980-2015)$ \\
\hline Nid d'Aigle & Bionnassay & $1750 \mathrm{~m}$ & $-325 \mathrm{~m}(1988-2021)^{2}$ & $\mathrm{n} / \mathrm{a}$ & $\mathrm{n} / \mathrm{a}$ \\
\hline Glacier Blanc & Glacier Blanc & $2600 \mathrm{~m}$ & -742 m (1986-2015) & $-170 \mathrm{~m}(1904-2014)^{3}$ & $\mathrm{n} / \mathrm{a}$ \\
\hline Eggishorn & Aletsch Glacier & $1700 \mathrm{~m}$ & -2317 m (1950-2019) & $-230 \mathrm{~m}(1960-2016)^{4}$ & $\mathrm{n} / \mathrm{a}$ \\
\hline Rhône Glacier & Rhône Glacier & $2200 \mathrm{~m}$ & -604 m (1950-2019) & $\mathrm{n} / \mathrm{a}$ & $-5 \mathrm{~m} \cdot \mathrm{a}^{-1}(2000-2006)$ \\
\hline Franz-Josefs-Höhe & Pasterze Glacier & $2000 \mathrm{~m}$ & $-1100 \mathrm{~m}(1964-2015)$ & $-70 \mathrm{~m}(1999-2011)^{5}$ & $-10 \mathrm{~m} \cdot \mathrm{a}^{-1}(1999-2011)$ \\
\hline
\end{tabular}

\footnotetext{
${ }^{1}$ At the Montenvers profile (see Vincent et al. 2019)

${ }^{2}$ Own measurement $( \pm 10 \mathrm{~m})$

${ }^{3}$ Average thickness change on the glacier tongue (see Bonnefoy-Demogeot and Thibert 2018)

${ }^{4}$ On the cross-profile 'C' (see Kos et al. 2016)

${ }^{5}$ On the glacier tongue (see Kellerer-Pirklbauer and Kulmer, 2018)
}

General descriptors are used to protect the anonymity of the interviewees. Direct content analysis was applied (Hsieh and Shannon 2005), allowing the development of a first coding based on a theoretical category, in this case, climate change effects and adaptation. In the second step, a more inductive approach was applied to underline the different effects of climate change and adaptation strategies developed without using a preconceived category.

\section{Results}

\section{Processes studied in glacier tourism areas}

The 73 papers included in the analysis identify 14 processes and parameters grouped into four main categories: glacierrelated processes (Table 1), paraglacial-related processes (i.e. directly conditioned by former glaciation and deglaciation; Ballantyne 2002), permafrost-related processes, and the 'other' category concerning the air temperature as a studied parameter. Among the 73 papers, 48 refer to a process or parameter in an area directly related to one of the study sites.

The most studied glacier parameter concerns the evolution of the glacier length. This evolution is studied at all sites and exhibits a significant retreat in recent years. The Pasterze glacier retreated by about $1.1 \mathrm{~km}$ from 1964 to 2015 (Lieb and Kellerer-Pirklbauer 2018), and the Glacier Blanc retreated by $742 \mathrm{~m}$ from 1986 to 2015 while its front rose by about $200 \mathrm{~m}$ in altitude (Bayle 2020).

The second-most studied parameter concerns the loss of glacier thickness. This parameter was significant for all the measured glaciers (Bonnefoy-Demongeot and Thibert 2018; Gobiet et al. 2014; Tsutaki et al. 2011; Vincent et al. 2019).

The evolution of glacier velocity is the third parameter, which was only studied at the Mer de Glace (Peyaud et al. 2020), Rhône (Nishimura et al. 2013), and Pasterze glaciers
(Kellerer-Pirklbauer and Kulmer 2019). For example, ice velocity at the tongue decreased from $75 \mathrm{~m}^{-\mathrm{a}^{-1}}$ in 1980 to about $20 \mathrm{~m} \cdot \mathrm{a}^{-1}$ in 2015 at Mer de Glace (Peyaud et al. 2020) and decreased from $15 \mathrm{~m} \cdot \mathrm{a}^{-1}$ in 1999 to $5 \mathrm{~m} \cdot \mathrm{a}^{-1}$ in 2011 at the Pasterze glacier (Kellerer-Pirklbauer and Kulmer 2019).

Water pockets, which can generate outbursts of flooding, have been studied at the Tête Rousse glacier in the Mont Blanc massif (Gilbert et al. 2012). The extent of the debris covering the glacier surface has been studied at several sites (Kaufmann et al. 2015; Lardeux et al. 2015; Avian et al. 2018). Finally, the warming of the ice at the base of hanging glaciers, possibly leading to destabilisation, has been studied at the Mont Blanc massif (Deline et al. 2012; Gilbert et al. 2015). The present and future formations of proglacial lakes have been studied, particularly around the Pasterze glacier (Avian et al. 2020), Rhône glacier (Church et al. 2018) and Mer de Glace (Magnin et al. 2020).

Two processes associated with the present paraglacial period have also been studied at every site. The first one is glacial debuttressing (Deline et al. 2012), which leads to landslides, as observed in the left lateral moraine of the Aletsch glacier in 2015, resulting in a volume of about $50,000 \mathrm{~m}^{3}$ (Kos et al. 2016), and around the proglacial lake of the Pasterze glacier (Avian et al. 2020). The consequences of debuttressing on the access to huts have also been studied, for example, in the Mer de Glace basin (Mourey and Ravanel 2017).

These studies have demonstrated that paraglacial dynamics have forced changes in the itinerary and have become more frequent and intense since 1990 (Mourey, et al. 2019a,b; Mourey and Ravanel 2017). Mourey, et al. $(2019 a, b)$ indicated that the effects of the current paraglacial period on itineraries include an increase in the height of moraines with steeper slopes, the destabilisation of some of them, leading to rock falls, and the development of proglacial torrents, which can make some sections inaccessible. 


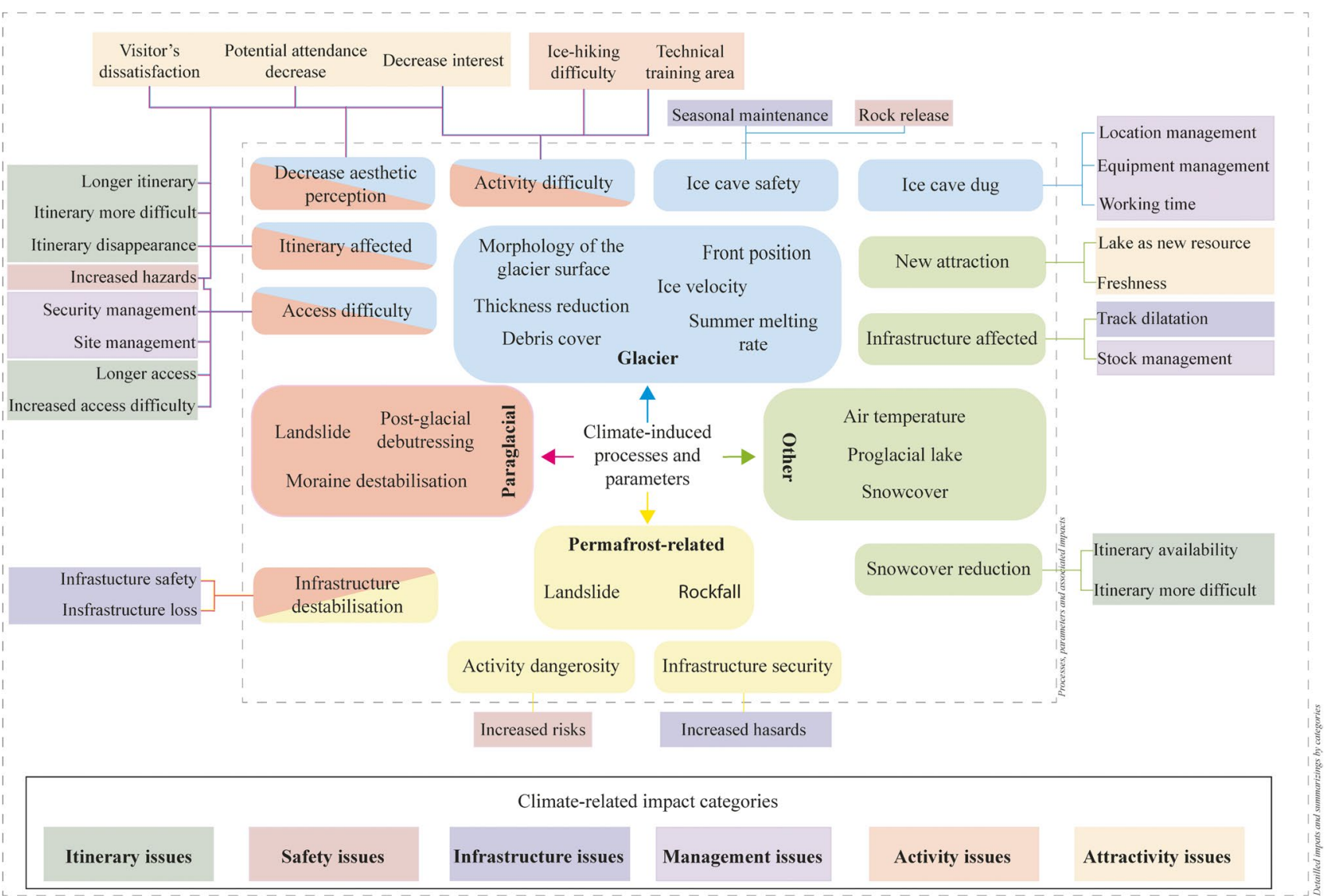

Fig. 2 Processes, parameters, and associated effects. The centre of the figure presents four families of processes and parameters studied in the scientific literature. The first family of effects is associated with each of the families of processes. In the outer part of the frame, each family of effects is detailed. The colour code corresponds to the developed effect categories
The third process category concerns permafrost. The warming of the permafrost and the rock instability it induces are the two primary processes studied, especially in the Mont Blanc massif (e.g. Magnin et al. 2017; Ravanel et al. 2017; Gallach et al. 2018) but also on a larger scale (e.g. Gobiet et al. 2014; Haeberli et al. 2017; Stoffel et al. 2014). Ravanel et al. (2017) demonstrated that the heatwaves of 2003 and 2015 increased permafrost-related rockfall volumes in the Mont Blanc massif, and Magnin et al. (2017) found that increased temperature extended the warm permafrost $\left(>-2{ }^{\circ} \mathrm{C}\right)$ by up to $4300 \mathrm{~m}$ a.s.l. during the twentyfirst century. The effects of permafrost warming on tourism infrastructure have been recently studied in the Alps (e.g. Duvillard et al. 2015, 2019; Patton et al. 2019). For example, Duvillard et al. (2019) found that more than 1000 infrastructures were built in the context of permafrost in the French Alps and that 12 of them have already been affected by its warming, resulting in costly adaptations.

Pohl et al. (2019) studied the evolution of the number of frost days for the Mont Blanc massif. They revealed that the frequency of frost occurrence could fall by $50 \%$ by the end of the century, between 3500 and $4500 \mathrm{~m}$ a.s.l., according to modelling based on IPCC scenario RCP8.5. Among the three categories of processes studied around the selected sites, the 'glacier' is the one that has been studied the longest, whereas paraglacial and permafrost-related processes have been increasingly studied since 2010 .

\section{Effects perceived by stakeholders}

The interviews revealed that the effects induced by the four categories of processes related to climate change, identified through the literature review, are well perceived by tourist site stakeholders in addition to an added category related to snow cover. These effects have six types: itinerary, safety, infrastructure, management, activity, and attractivity issues (Fig. 2).

(i) The first type concerns itinerary issues, primarily caused by the glacier or paraglacial processes, such as increasing the length of access itineraries due to the glacier retreat and extension of the proglacial margin. This situation is the case at Montenvers and Franz-Josefs- Höhe; the return 
Table 2 Occurrence of mention of each issue by type of stakeholder

\begin{tabular}{|c|c|c|c|}
\hline Issue & Occurrence & Stakeholders & $\begin{array}{c}\text { No. of } \\
\text { stakeholders }\end{array}$ \\
\hline \multirow{3}{*}{ Itinerary issues } & \multirow{3}{*}{16} & Mountain guide & 8 \\
\hline & & Infrastructure manager & 4 \\
\hline & & Public operator & 4 \\
\hline \multirow{3}{*}{ Activity issues } & \multirow{3}{*}{15} & Mountain guide & 6 \\
\hline & & Infrastructure manager & 5 \\
\hline & & Public operator & 4 \\
\hline \multirow{3}{*}{ Attractivity issues } & \multirow{3}{*}{14} & Infrastructure manager & 6 \\
\hline & & Public operator & 4 \\
\hline & & Mountain guide & 4 \\
\hline \multirow{3}{*}{ Safety issues } & \multirow{3}{*}{12} & Infrastructure manager & 6 \\
\hline & & Mountain guide & 4 \\
\hline & & Public operator & 2 \\
\hline \multirow{3}{*}{ Infrastructure issues } & \multirow{3}{*}{12} & Infrastructure manager & 8 \\
\hline & & Public operator & 4 \\
\hline & & Mountain guide & 0 \\
\hline \multirow{3}{*}{ Management issues } & \multirow{3}{*}{4} & Infrastructure manager & 4 \\
\hline & & Public operator & 0 \\
\hline & & Mountain guide & 0 \\
\hline
\end{tabular}

trip duration between the access infrastructures (cog railway or car park) and the glacier has increasingly become longer. Some itineraries take longer to be followed. For example, the ski descent of the Vallée Blanche (Montenvers) takes more time because of the development of debris covering the glacier and the reduced snow cover. Thus, it is sometimes necessary to walk more than $1 \mathrm{~km}$ rather than ski. Itineraries can also become more challenging for the mountaineering routes around most sites. The glacial retreat leads to an increase in the slope angle, and the difficulty of the first climbing pitches newly free of ice can be greater than that of the rest of the route. Access also becomes more difficult because of the destabilisation of moraines, as in the access to the Écrins hut. Finally, some itineraries may disappear, as Alpine routes or walking paths may become temporarily or permanently inaccessible. An example is the path along the lateral moraine of the Aletsch glacier, which has been closed due to a large landslide (Kos et al. 2016).

(ii) The second type concerns safety issues derived from the glacier, paraglacial dynamics and permafrost-related processes. Rockfalls due to permafrost warming endanger mountaineering routes. Summer melting of the glacier releases boulders that can fall on visitors at the entrance of ice caves at the Rhône glacier and Mer de Glace. Moraine destabilisation affecting itineraries and accesses can be a source of hazards.

(iii) Infrastructure issues can be related to all observed processes. Infrastructure is destabilised because of permafrost warming (e.g. the arrival station of the Eggishorn cable car) or glacial debuttressing (e.g. the Moosfluh cable car at Aletsch). Permafrost degradation also leads to increased risks for downstream infrastructures, such as at FranzJosefs-Höhe. The digging of ice caves is also affected. At Mer de Glace, the cave is dug at approximately the same place every year. Glacioclim measurements (Vincent et al. 2007) show that at the location where the cave is dug, the glacier's speed has decreased from $49 \mathrm{~m} \cdot \mathrm{a}^{-1}$ in 2000 to $11 \mathrm{~m}$. $\mathrm{a}^{-1}$ in 2019. As a result, the cave can no longer be dug in the same place every year for stability reasons. Finally, higher summer temperatures-particularly heatwaves—can affect infrastructure. For example, access by cogwheel train to Nid d'Aigle stops when the temperature is too high, resulting in the expansion of the rails on portions suffering from design weaknesses.

(iv) The various processes and their consequences can lead to management issues. This issue can cascade from the itinerary issue. For example, the increasing access time needed to return from the glacier to the Montenvers train 


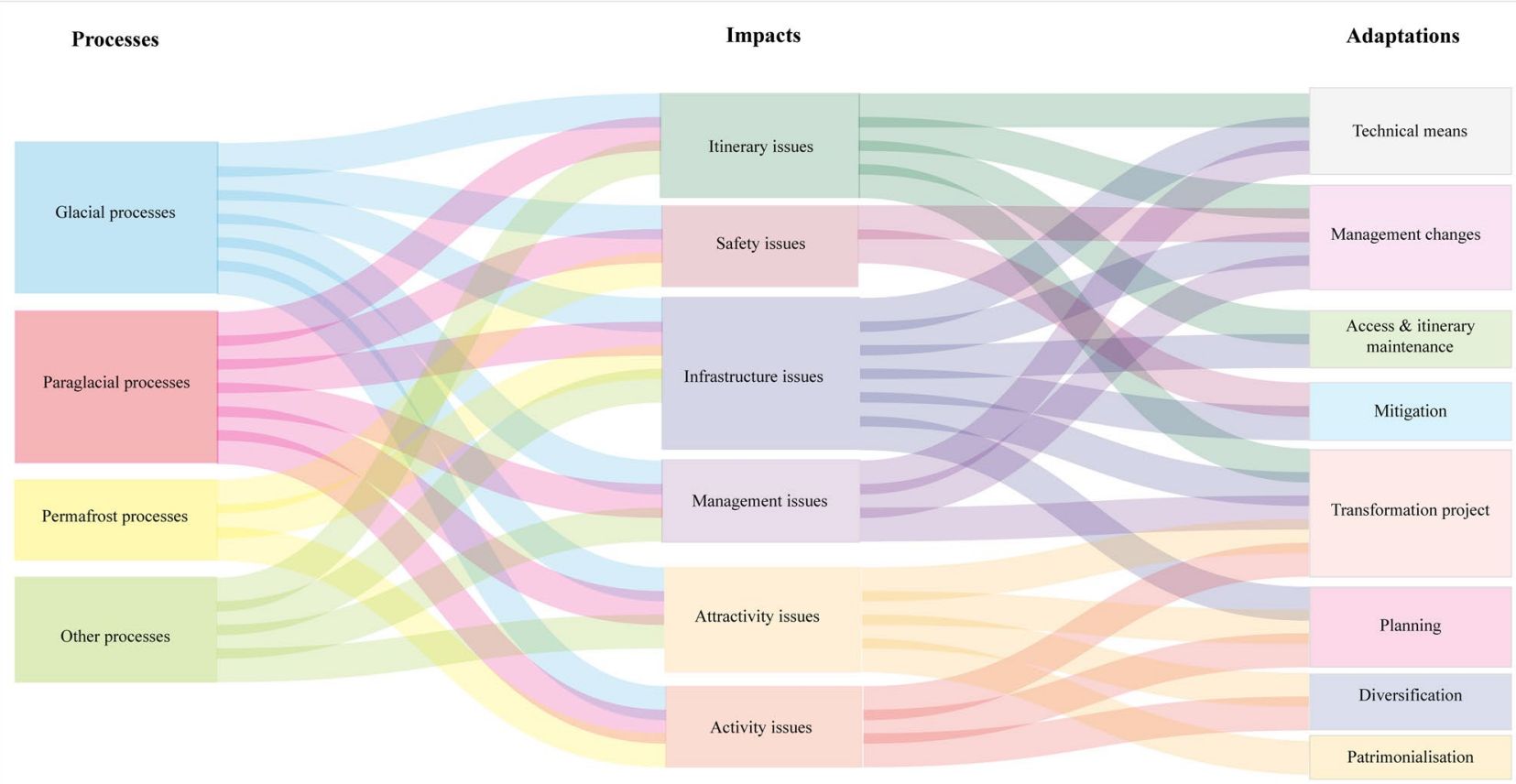

Fig. 3 Relations between processes, effects, and adaptation strategies

station requires the installation of a watchpoint to guarantee visitor safety, additional time in winter to clear the snow from the 550 steps leading up from the ice cave gondola to the train station, and longer train operating times to guarantee the return journey. This issue can also be the result of physical processes. As an example, for ice caves, the summer melt means that more work must be done to keep the ice cave visitable during the summer. In addition, rising summer temperatures cause stock management problems. For example, at the Écrins hut, conserving a large quantity of food for the entire opening season is no longer possible.

(v) The following type concerns activity issues dominated mainly by the glacier and paraglacial processes and dynamics. The retreat of the glacier front and thickness make access to the glacier more physically challenging, reducing the time spent on the ice and the interest in the activity. Glacier retreat limits the potential for easy glacier climbing, reduces the possibilities for mountain guides to organise technical training on the ice, and forces them to reduce the number of clients they lead, raising the cost of individual ascent. The first reason for this is that the development of the debris covering hampers the realisation of exercises on the ice, and the glacier retreat sometimes increases the slope angle resulting in a more challenging route (a typical example is access to Dôme des Écrins). Contrastingly, the second reason is that, as the glacier melts, some parts become flatter. Thus, the ice walls used for some exercises no longer exist (a typical example is the tongue of Mer de Glace).

(vi) Finally, these elements and the landscape modification due to the decrease in ice volume and increase in debris cover have led to attractivity issues, a potential decrease in visitor satisfaction, and a potential decline in the number of future visitors. Further, managers indicate that new attractions may emerge, such as new lakes or the relatively fresh temperature at these altitudes compared to the valleys.

The presented issues are not equally perceived by various stakeholders (Table 2). The itinerary issue, which is the most frequent issue mentioned, is perceived by almost all mountain guides but only half of the infrastructure managers. In contrast, the management issue, the least perceived issue, is only perceived by infrastructure managers. These results, presented in Table 2 , should be treated with caution. Many interviewees mention specific issues, but they may be the same problem mentioned from different viewpoints. In contrast, a less perceived issue may be relevant only for one type of stakeholder (infrastructure issue is a good example, as mountain guides do not have to manage infrastructure).

\section{Adaptation strategies developed}

Analysis of the interviews indicates that 29 different adaptation strategies have been implemented to address the effects of climate change described above. The strategies can be arranged into eight categories (Fig. 3; Table 3).

Four categories concern more or less short-term adaptations. First, technical means correspond to technological and technical solutions. Examples are the safety structures at the Franz-Josefs-Höhe to cope with permafrost issues, flexible piles under the Moosfluh lift to adapt to landslides, and relocation of the Montenvers ice cave to cope with the 
Table 3 Summary of adaptation strategies and their respective adaptation categories

Adaptation categories

\begin{tabular}{|c|c|}
\hline \multirow{4}{*}{ Heritage } & Glaciological lectures \\
\hline & Interpretation centre \\
\hline & Site scenario \\
\hline & Interpretation guided tour \\
\hline \multirow{5}{*}{ Diversification } & Narrative changes \\
\hline & Proglacial lake investigation for tourism \\
\hline & Change mountain guide activity \\
\hline & Change hut proposal \\
\hline & Last Chance Tourism Marketing \\
\hline \multirow{2}{*}{ Mitigation } & Glacier blanket cover \\
\hline & Monitoring system \\
\hline \multirow{5}{*}{ Technical means } & Spatial changes for infrastructures \\
\hline & Rail refreshment \\
\hline & New material \\
\hline & Security infrastructures \\
\hline & Flexible pile \\
\hline \multirow{4}{*}{ Access \& itinerary maintenance } & Remove itinerary \\
\hline & Modified itinerary \\
\hline & New itinerary \\
\hline & New access and security infrastructures \\
\hline \multirow{5}{*}{ Management transformation } & Opening length change \\
\hline & Lower customer numbers \\
\hline & Temporal change \\
\hline & Early seasonal closing \\
\hline & Increase labour time/day \\
\hline Transformation project & $\begin{array}{l}\text { Nid d'Aigle project } \\
\text { Montenvers project }\end{array}$ \\
\hline \multirow{2}{*}{ Planning } & Stakeholder planning \\
\hline & Balancing conservation and development \\
\hline \multicolumn{2}{|l|}{ Colour code: adaptation types } \\
\hline \multicolumn{2}{|l|}{ Reactive } \\
\hline \multicolumn{2}{|l|}{ Incremental } \\
\hline Transformative & \\
\hline
\end{tabular}


Table 4 Occurrence of mention of each adaptation strategy by stakeholder type

\begin{tabular}{|c|c|c|c|}
\hline Adaptation & Occurrence & Stakeholders & $\begin{array}{c}\text { No. of } \\
\text { stakeholders } \\
\end{array}$ \\
\hline \multirow{3}{*}{ Diversification } & \multirow{3}{*}{15} & Public operator & 6 \\
\hline & & Mountain guide & 5 \\
\hline & & Infrastructure manager & 4 \\
\hline \multirow{3}{*}{ Itinerary and access maintenance } & \multirow{3}{*}{13} & Mountain guide & 6 \\
\hline & & Public operator & 4 \\
\hline & & Infrastructure manager & 3 \\
\hline \multirow{3}{*}{ Technical means } & \multirow{3}{*}{11} & Infrastructure manager & 8 \\
\hline & & Public operator & 3 \\
\hline & & Mountain guide & 0 \\
\hline \multirow{3}{*}{ Heritage } & \multirow{3}{*}{10} & Infrastructure manager & 5 \\
\hline & & Public operator & 5 \\
\hline & & Mountain guide & 0 \\
\hline \multirow{3}{*}{ Management change } & \multirow{3}{*}{9} & Mountain guide & 5 \\
\hline & & Infrastructure manager & 4 \\
\hline & & Public operator & 0 \\
\hline \multirow{3}{*}{ Transformation project } & \multirow{3}{*}{7} & Infrastructure manager & 5 \\
\hline & & Public operator & 2 \\
\hline & & Mountain guide & 0 \\
\hline \multirow{3}{*}{ Planning } & \multirow{3}{*}{5} & Infrastructure manager & 3 \\
\hline & & Public operator & 2 \\
\hline & & Mountain guide & 0 \\
\hline \multirow{3}{*}{ Mitigation } & \multirow{3}{*}{4} & Infrastructure manager & 3 \\
\hline & & Public operator & 1 \\
\hline & & Mountain guide & 0 \\
\hline
\end{tabular}

slowing and retreat of the glacier. The second category is management changes, such as altering the opening hours of sites (e.g. at Montenvers), introducing surveillance staff to guarantee visitor safety when access times are extended, or increasing maintenance work at the Rhône glacier to ensure safe summer exploitation. The third category is itinerary and access maintenance, for example, by adding safety or progression infrastructure to the existing infrastructure, creating new itineraries that can lead to tension and conflicts with protected areas and environmental protection associations, or closing some of the most affected itineraries. Finally, the fourth is mitigation, aimed at reducing the glacier retreat rate, primarily by installing protective covers to limit summer melting around ice caves. This strategy allows the manager to operate the infrastructure over more extended periods and protect visitors from rockfalls.
The four other strategies aim at longer-term developments. The fifth strategy is transformation projects, such as at Montenvers and Nid d'Aigle, where operators try to respond to issues related to climate change by redefining the tourist offer. Valorisation methods have been redesigned, and marketing catchphrases have been modified. At Montenvers, managers intend to reduce the place of the glacier in the marketing elements to anticipate its disappearance. They focus communications on the historical and scientific aspects of the area. The sixth strategy, planning between stakeholders, has also been implemented, for example, concerning problems linked to infrastructure or the management of access routes to and from the Écrins hut. The seventh strategy involves the loss of attractiveness of certain sites and the difficulty of carrying out some activities, which has pushed stakeholders towards diversification. Mountain guides now 


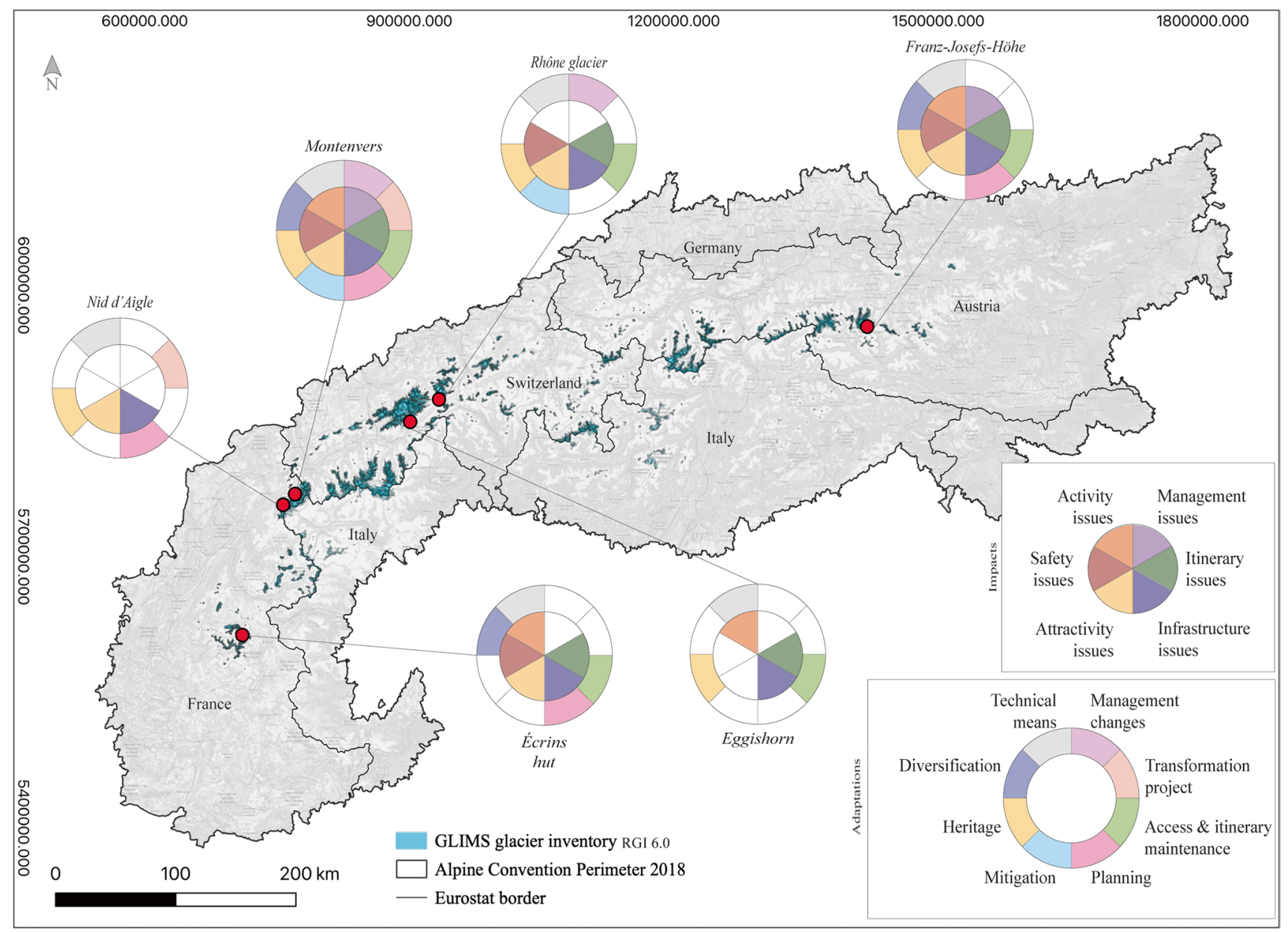

Fig. 4 Spatialisation of identified effects and adaptations. The inner circle indicates the presence or absence (blank) of the effect category. The outer circle indicates whether the adaptation category is observed at the site

propose new activities to substitute ice walking initiation, and mountain hut keepers organise artistic, heritage, and festive events for new visitors. In contrast to transformation, diversification involves the addition of new activities without abandoning the old ones. Finally, the strategy regarding glacier heritage, which consists of patrimonialisation of glaciers, can be observed at all sites, with the creation of interpretation panels or the construction of glacier interpretation centres and hikes with the mediation of scientists.

Similar to the issue section, the presented adaptation strategies vary according to the stakeholder type (Table 4). For example, the diversification strategy is implemented by all types of stakeholders. In contrast, the mitigation strategy is only implemented by public and infrastructure operators. These results should be taken with caution for the same reason as the issue results. The effects of climate change on glacier tourism sites and the adaptation strategies deployed to address them vary across the Alps. Figure 4 summarises the climate change effects and adaptations implemented by stakeholders for each site.

\section{Discussion}

\section{Studied and perceived processes and effects}

The three main categories of processes investigated in the scientific literature and areas close to the selected glacier tourism sites (i.e. glacier, paraglacial and permafrostrelated processes) are also categories of processes perceived by interviewees as influencing Alpine glacier tourism sites. As demonstrated in other areas (Furunes and Mykletun 2012; Purdie 2013; Stewart et al. 2016), Alpine glacier tourism is strongly challenged by climate change consequences.

Among the 13 processes recognised from the literature review, 12 are perceived by tourism operators. The only process that was not mentioned in the interviews is the formation of englacial water pockets. This outcome may indicate that this hazard, which would directly threaten one of the sites (Nid d'Aigle), is not perceived as a threat by the operators. A possible reason is that this threat is well monitored. 
The numbers and importance of processes perceived by stakeholders vary according to the site, depending on the activity type proposed on the glacier. For example, stakeholders perceived the most negligible effects in terms of numbers at Nid d'Aigle, but it is also the only site that does not provide activities on the glacier. The perception of effects also depends on the rapidity of the glacier retreat. At Montenvers, where the glacier is retreating very quickly and visibly (Peyaud et al. 2020), managers of the private company are much more worried than those around the Aletsch glacier, whose vanishing will take much longer (Jouvet and Huss 2019).

As observed in other places (e.g. Stewart et al. 2016; Welling and Abegg 2019), climate change induces access and itinerary issues at sites with glacier access. As in Norway and Iceland (Furunes and Mykletun 2012; Welling and Abegg 2019), the quality and sometimes feasibility of glacier activities have been reduced. Safety issues are comparable to those in New Zealand and Nepal (Purdie et al. 2015; Watson and King 2018). Such infrastructure issues occur in Iceland (Welling and Abegg 2019), and these management issues occur in New Zealand (Stewart et al. 2016). Finally, attractivity issues are common to all study sites except for the Aletsch glacier, whose managers consider that its size pushes back the question for decades. It is also a core issue emerging in glacier tourism studies worldwide (Welling et al. 2015; Wang and Zhou 2019; Salim et al. 2021a).

\section{Adapting glacier tourism to climate change}

Similar to the results by Salim et al. (2021a) about glacier tourism, an essential part of the mentioned adaptation strategies is reactive or incremental (Table 3). Among the eight categories of identified adaptations, two (technical means and mitigation) include only reactive strategies. According to Fedele et al. (2019), reactive strategies are implemented when effects are not severe or when stakeholders do not have the technology or means to answer in another way. In the observed cases, reactive strategies are implemented when their cost is low enough to cope with relatively slight effects. For example, access infrastructure to the Mer de Glace and Pasterze glaciers are set up because the cost remains low compared to the benefits (allowing activities to continue). This tendency can be considered in the context of the built-in permafrost infrastructure, where the majority of the developed adaptation strategies are reactive (Duvillard et al. 2021). However, reactive strategies may fail in the long term, for example, in the case of the installation of covers on the Rhône Glacier and Mer de Glace. Nevertheless, these strategies may extend the operating period while waiting to implement longer-term strategies or even considering an end to the activity. As one of the ice cave managers stated, these adaptations 'are short-term solutions. Well, on the long term, we know very well, me and my team, that it's not going to continue'.
In this case, as described by Fedele et al. (2019), incremental strategies are reflected by such strategies as the creation or modification of itineraries or changes in staff organisation, the opening season, or the practice calendar by shifting to winter or spring to take advantage of the presence of snow. These adaptation strategies allow the activity to continue by changing organisations and practices. However, it does not allow the vulnerabilities to be overcome. As such, heritage is an adaptation category that falls entirely within this framework. As carried out on the investigated sites, this strategy allows visitors to better understand the landscape but remains utterly dependent on the glacier as the only medium. From this viewpoint, it can be a strategy to move to a new model that meets visitors' motivations and expectations (Salim and Ravanel 2020).

Transformative adaptation strategies are relatively rare, as in other contexts (Fedele et al. 2020). They primarily consist of planning changes in the narrative of the site. For example, Montenvers managers changed their marketing strategy by focusing on historical aspects and natural elements, and the site will become a 'climate change laboratory'. The other major category of transformative adaptation is illustrated by transformation projects, which involve implementing costly projects that completely redesign a site, such as Nid d'Aigle. Similar to glacier tourism worldwide (Salim et al. 2021a), the largest tourism operators can implement transformative adaptation strategies when they perceive a significant threat to their business for the future.

Conversely, entrepreneurs or small companies often do not have the technical, temporal, or financial means to make transformative changes. For example, high mountain guides must continuously manage their activity, making it challenging to plan a change over the long term. In addition, they can increase their geographical mobility to find higher sites offering even better glacial conditions to extend their usual practices (Bourdeau et al. 2021). Welling and Abegg (2019) emphasised that this situation results in decisions that are not undertaken. However, the hut keepers who are forced to adapt on the spot are organising themselves to welcome new clients and propose new activities or alternative practices and objectives.

\section{An upcoming world without ice}

According to the IPCC scenarios, Central Europe will potentially lose about $60 \%$ to $99 \%$ of its ice volume by the end of this century (Bosson et al. 2019). Mer de Glace will no longer be visible from the Montenvers viewpoint in less than 30 years (Peyaud et al. 2020), and the Aletsch Glacier tongue could disappear before 2100 (Jouvet and Huss 2019). Accordingly, pursuing and adapting activities while maintaining dependency on ice is doomed to failure in the long term (decades). Coping and incremental adaptations are therefore useful as adaptations that facilitate the transition of tourism stakeholders. 
Transition management (Gössling et al. 2012) is recommended in this case to ensure the sustainability of activities in the future. A transdisciplinary approach (Otero et al. 2020), describing a reflection involving all partiesincluding researchers-could allow the tourism offer to be renewed. Moreover, transdisciplinarity offers an opportunity to redesign glacier tourism to achieve sustainable development goals (UNWTO and UNDP 2017).

\section{Conclusions}

As occurring worldwide, glacier tourism sites in the European Alps are severely affected by climate change. Glacier retreat and the associated paraglacial dynamics and permafrost degradation, which have been studied by scientists, are also perceived by Alpine glacier tourism stakeholders. Rising air temperature, proglacial lake formation, and reduced snow cover also influence glacier tourism sites. The consequences of the glacio-geomorphological changes on glacier tourism include issues related to itineraries and glacier access, reduction of visitor safety and infrastructure, management issues and, finally, challenges to the proposed activities and attractiveness of the sites.

Site managers, entrepreneurs offering site activities, and public institutions have been adapting by responding with technical means, management evolution, ice-melt mitigation, activity diversification, management of glacier itineraries and access, planning, and glacier heritage and transformation projects. Most of these adaptations allow activities to continue in the short (years) and middle (decade) terms but do not necessarily guarantee long-term site sustainability (few decades).

Furthermore, big companies can adapt sustainably by planning long-term changes that small companies cannot. In many cases, however, independent actors (mountain guides and hut keepers) are more flexible and have more substantial capacity for incremental and transformative adaptation than more structured organisations. Because glacier evolution in the coming decades will lead to the disappearance of these tourist glaciers, transformative projects must begin today. Accordingly, the coping and incremental adaptation strategies can be viewed as transitional strategies that must include innovations to favour the emergence of new models. Planning and cooperation between stakeholders and researchers should be engaged to face the immense challenges that are coming. Trans- and inter-disciplinarity appears crucial to ensure that stakeholders have all the necessary knowledge to make decisions that will guarantee sustainability. In any case, stakeholders should already be considering their futures in the post-glacial era.

Supplementary Information The online version contains supplementary material available at https://doi.org/10.1007/s10113-021-01849-0.

\section{References}

Adger WN, Brown K, Nelson DR, Berkes F, Eakin H, et al (2011) Resilience implications of policy responses to climate change. Wires Clim Change 2(5):757-766. https://doi.org/10.1002/wcc.133

Avian M, Bauer C, Schlögl M, Widhalm B, Gutjahr K-H, et al (2020) The status of earth observation techniques in monitoring high mountain environments at the example of Pasterze glacier, Austria: Data, methods, accuracies, processes, and scales. Remote Sensing 12(8):1251. https://doi.org/10.3390/rs12081251

Avian M, Kellerer-Pirklbauer A, Lieb GK (2018) Geomorphic consequences of rapid deglaciation at Pasterze Glacier, Hohe Tauern Range, Austria, between 2010 and 2013 based on repeated terrestrial laser scanning data. Geomorphology 310:1-14. https:// doi.org/10.1016/j.geomorph.2018.02.003

Ballantyne CK (2002) Paraglacial geomorphology. Quatern Sci Rev 21(18):1935-2017. https://doi.org/10.1016/S0277-3791(02)00005-7

Bayle A (2020) A recent history of deglaciation and vegetation establishment in a contrasted geomorphological context, Glacier Blanc. French Alps Journal of Maps 16(2):766-775. https://doi.org/10. 1080/17445647.2020.1829115

Bonnefoy-Demongeot M, Thibert E (2018) A century of volume changes of Glacier Blanc (Ecrins Range, French Alps) from historical maps and aerial photogrammetry. In: 20th EGU General Assembly, EGU2018, Proceedings from the conference held 4-13 April, 2018 in Vienna, Austria, p 7352

Bosson J-B, Huss M, Osipova E (2019) Disappearing world heritage glaciers as a keystone of nature conservation in a changing climate. Earth's Future 7:469-479. https://doi.org/10.1029/2018EF001139

Bourdeau P, Mourey J, Ravanel L (2021) Le changement climatique comme facteur de transformation des pratiquesde l'alpinisme. Etude de cas dans les massifs du Mont Blanc, des Ecrins(France) et des Alpes Valaisannes (Suisses). In: Debons D, Pitteloud J-F, Clastres P, Quin Q (eds) Gravir les Alpes du XIXe siècle à nos jours. Pratiques, émotions, imaginaires. Presses Universitaires de Rennes

Church GJ, Bauder A, Grab M, Hellmann S, Maurer H (2018) Highresolution helicopter-borne ground penetrating radar survey to determine glacier base topography and the outlook of a proglacial lake. 2018 17th International Conference on Ground Penetrating Radar (GPR), 1-4. https://doi.org/10.1109/ICGPR.2018.8441598

Dawson J, Stewart EJ, Johnston ME, Lemieux CJ (2016) Identifying and evaluating adaptation strategies for cruise tourism in Arctic Canada. J Sustain Tour 24(10):1425-1441. https://doi.org/10. 1080/09669582.2015.1125358

Deline P, Gardent M, Magnin F, Ravanel L (2012) The morphodynamics of the mont blanc massif in a changing cryosphere: A comprehensive review. Geogr Ann Ser B 94(2):265-283. https:// doi.org/10.1111/j.1468-0459.2012.00467.x

Demiroglu OC, Dannevig H, Aall C (2018) Climate change acknowledgement and responses of summer (glacier) ski visitors in Norway. Scand J Hosp Tour 18(4):419-438. https://doi.org/10.1080/ 15022250.2018 .1522721

Diolaiuti G, Smiraglia C (2010) Changing glaciers in a changing climate: How vanishing geomorphosites have been driving deep changes in mountain landscapes and environments. Geomorphol Relief Process Environ 16(vol. 16-n ${ }^{\circ}$ 2): 131-152. https://doi.org/ 10.4000/geomorphologie.7882

Duvillard P-A, Ravanel L, Deline P (2015) Risk assessment of infrastructure destabilisation due to global warming in the high French Alps. J Alp Res I Revue de Géographie Alpine 103-2. https://doi. org/10.4000/rga.2896

Duvillard P-A, Ravanel L, Marcer M, Schoeneich P (2019) Recent evolution of damage to infrastructure on permafrost in the French Alps. Reg Environ Change 19(5):1281-1293. https://doi.org/10. 1007/s10113-019-01465-Z 
Duvillard P-A, Ravanel L, Schoeneich P, Deline P, Marcer M, et al (2021) Qualitative risk assessment and strategies for infrastructure on permafrost in the French Alps. Cold Reg Sci Technol 189:103311. https://doi.org/10.1016/j.coldregions.2021.103311

Espiner S, Orchiston C, Higham J (2017) Resilience and sustainability: A complementary relationship? Towards a practical conceptual model for the sustainability-resilience nexus in tourism. J Sustain Tour 25(10):1385-1400. https://doi.org/10.1080/09669582.2017. 1281929

Fedele G, Donatti CI, Harvey CA, Hannah L, Hole DG (2019) Transformative adaptation to climate change for sustainable socialecological systems. Environ Sci Policy 101:116-125. https://doi. org/10.1016/j.envsci.2019.07.001

Fedele G, Donatti CI, Harvey CA, Hannah L, Hole DG (2020) Limited use of transformative adaptation in response to social-ecological shifts driven by climate change. Ecol Soc 25(1):25. https://doi. org/10.5751/ES-11381-250125

Furunes T, Mykletun RJ (2012) Frozen adventure at risk? A 7-year follow-up study of Norwegian Glacier Tourism. Scand J Hosp Tour 12(4):324-348. https://doi.org/10.1080/15022250.2012.748507

Gallach X, Ravanel L, Egli M, Brandova D, Schaepman M, et al (2018) Timing of rockfalls in the Mont Blanc massif (Western Alps): Evidence from surface exposure dating with cosmogenic 10Be. Landslides 15(10):1991-2000. https://doi.org/10.1007/ s10346-018-0999-8

Garavaglia V, Diolaiuti G, Smiraglia C, Pasquale V, Pelfini M (2012) Evaluating tourist perception of environmental changes as a contribution to managing natural resources in glacierized areas: A case study of the Forni Glacier (Stelvio National Park, Italian Alps). Environ Manage 50(6):1125-1138. https://doi.org/10.1007/ s00267-012-9948-9

Gilaberte-Búrdalo M, López-Martín F, Pino-Otín MR, López-Moreno JI (2014) Impacts of climate change on ski industry. Environ Sci Policy 44:51-61. https://doi.org/10.1016/j.envsci.2014.07.003

Gilbert A, Vincent C, Gagliardini O, Krug J, Berthier E (2015) Assessment of thermal change in cold avalanching glaciers in relation to climate warming. Geophys Res Lett 42(15):6382-6390. https:// doi.org/10.1002/2015GL064838

Gilbert A, Vincent C, Wagnon P, Thibert E, Rabatel A (2012) The influence of snow cover thickness on the thermal regime of Tête Rousse Glacier (Mont Blanc range, $3200 \mathrm{~m}$ a.s.1.): Consequences for outburst flood hazards and glacier response to climate change. J Geophys Res: Earth Surf 117(F4). https://doi.org/10.1029/2011JF002258

Gobiet A, Kotlarski S, Beniston M, Heinrich G, Rajczak J, et al (2014) 21st century climate change in the European Alps-A review. Sci Total Environ 493:1138-1151. https://doi.org/10.1016/j.scitotenv. 2013.07.050

Gössling S, Hall CM, Ekström F, Engeset AB, Aall C (2012) Transition management: A tool for implementing sustainable tourism scenarios? J Sustain Tour 20(6):899-916. https://doi.org/10.1080/ 09669582.2012.699062

Groulx M, Lemieux CJ, Lewis JL, Brown S (2016) Understanding consumer behaviour and adaptation planning responses to climate-driven environmental change in Canada's parks and protected areas: A climate futurescapes approach. J Environ Planning Manage 60(6):1016-1035. https://doi.org/10.1080/09640 568.2016.1192024

Haeberli W, Schaub Y, Huggel C (2017) Increasing risks related to landslides from degrading permafrost into new lakes in de-glaciating mountain ranges. Geomorphology 293:405-417. https://doi. org/10.1016/j.geomorph.2016.02.009

Hsieh H-F, Shannon SE (2005) Three approaches to qualitative content analysis. Qual Health Res 15(9):1277-1288. https://doi.org/10. $1177 / 1049732305276687$

IPCC (2014) Climate change 2014: synthesis report. In: Core Writing Team, Pachauri RK, Meyer LA (eds) Contribution of working groups I, II and III to the fifth assessment report of the intergovernmental panel on climate change. IPCC, Geneva, pp 151

Joly M, Ungureanu EI (2018) Global warming and skiing: Analysis of the future of skiing in the Aosta Valley. Worldwide Hospitality and Tourism Themes 00-00.https://doi.org/10.1108/ WHATT-12-2017-0077

Jouvet G, Huss M (2019) Future retreat of Great Aletsch Glacier. J Glaciol 65(253):869-872. https://doi.org/10.1017/jog.2019.52

Kaenzig R, Rebetez M, Serquet G (2016) Climate change adaptation of the tourism sector in the Bolivian Andes. Tour Geogr 18(2):111128. https://doi.org/10.1080/14616688.2016.1144642

Kates RW, Travis WR, Wilbanks TJ (2012) Transformational adaptation when incremental adaptations to climate change are insufficient. Proc Natl Acad Sci 109(19):7156-7161. https://doi.org/ 10.1073/pnas.1115521109

Kaufmann V, Kellerer-Pirklbauer A, Lieb GK, Slupetzky H, Avian M (2015) Glaciological studies at Pasterze Glacier (Austria) based on aerial photographs. In J. Li \& X. Yang (Éds.). Monitoring and Modeling of Global Changes: A Geomatics Perspective (p. 173-198). Springer Netherlands. https://doi.org/10.1007/ 978-94-017-9813-6_9

Kellerer-Pirklbauer A, Kulmer B (2019) The evolution of brittle and ductile structures at the surface of a partly debris-covered, rapidly thinning and slowly moving glacier in 1998-2012 (Pasterze Glacier, Austria). Earth Surf Proc Land 44(5):1034-1049. https://doi.org/10.1002/esp.4552

Kos A, Amann F, Strozzi T, Delaloye R, von Ruette J, et al (2016) Contemporary glacier retreat triggers a rapid landslide response, Great Aletsch Glacier, Switzerland: GLACIER RETREAT TRIGGERS LARGE LANDSLIDE. Geophys Res Lett 43(24):12466-12474. https://doi.org/10.1002/2016GL071708

Kutzner D (2019) Environmental change, resilience, and adaptation in nature-based tourism: Conceptualizing the social-ecological resilience of birdwatching tour operations. J Sustain Tour 27(8):1-25. https://doi.org/10.1080/09669582.2019.1601730

Lambert E, Hunter C, Pierce GJ, MacLeod CD (2010) Sustainable whale-watching tourism and climate change: Towards a framework of resilience. J Sustain Tour 18(3):409-427. https://doi. org/10.1080/09669581003655497

Lardeux P, Glasser NF, Holt T, Irvine-Fynn TD, Hubbard BP (2015) Area and elevation changes of a debris-covered glacier and a clean-ice glacier between 1952-2013 using aerial images and structure-from-motion. AGU Fall Meeting Abstracts 13:C13B-0807

Lemieux CJ, Groulx M, Halpenny E, Stager H, Dawson J, et al (2018) "The end of the Ice Age?": Disappearing world heritage and the climate change communication imperative. Environ Commun 12(5):653-671. https://doi.org/10.1080/17524032.2017.1400454

Lieb GK, Kellerer-Pirklbauer A (2018) Die Pasterze, Österreichs größter Gletscher, und seine lange Messreihe in einer Ära massiven Gletscherschwundes. In A. Fischer, G. Patzelt, M. Achrainer, G. Groß, G. K. Lieb, A. Kellerer-Pirklbauer, \& G. Bendler (Éds.). Gletscher im Wandel: 125 Jahre Gletschermessdienst des Alpenvereins (p. 31-51). Springer. https://doi.org/10. 1007/978-3-662-55540-8_4

Magnin F, Haeberli W, Linsbauer A, Deline P, Ravanel L (2020) Estimating glacier-bed overdeepenings as possible sites of future lakes in the de-glaciating Mont Blanc massif (Western European Alps). Geomorphology 350:106913. https://doi.org/10.1016/j.geomorph. 2019.106913

Magnin F, Josnin J-Y, Ravanel L, Pergaud J, Pohl B, et al (2017) Modelling rock wall permafrost degradation in the Mont Blanc massif from the LIA to the end of the 21 st century. Cryosphere 11(4):1813-1834. https://doi.org/10.5194/tc-11-1813-2017

Mora C, Spirandelli D, Franklin EC, Lynham J, Kantar MB, et al (2018) Broad threat to humanity from cumulative climate hazards 
intensified by greenhouse gas emissions. Nature Climate Chang 8(12):1062-1071. https://doi.org/10.1038/s41558-018-0315-6

Mourey J, Marcuzzi M, Ravanel L, Pallandre F (2019a) Effects of climate change on high Alpine mountain environments: Evolution of mountaineering routes in the Mont Blanc massif (Western Alps) over half a century. Arct Antarct Alp Res 51(1):176-189. https:// doi.org/10.1080/15230430.2019.1612216

Mourey J, Ravanel L (2017) Evolution of access routes to high mountain refuges of the Mer de Glace Basin (Mont Blanc Massif, France). An example of adapting to climate change effects in the Alpine high mountains. J Alp Res I Revue de Géographie Alpine 105-4. https://doi.org/10.4000/rga.3790

Mourey J, Ravanel L, Lambiel C, Strecker J, Piccardi M (2019b) Access routes to high mountain huts facing climate-induced environmental changes and adaptive strategies in the Western Alps since the 1990s. Norsk Geografisk Tidsskrift - Norwegian Journal of Geography 73(4):215-228. https://doi.org/10.1080/00291951. 2019.1689163

Nishimura D, Sugiyama S, Bauder A, Funk M (2013) Changes in iceflow velocity and surface elevation from 1874 to 2006 in Rhonegletscher, Switzerland. Arct Antarct Alp Res 45(4):552-562. https://doi.org/10.1657/1938-4246-45.4.552

Otero I, Darbellay F, Reynard E, Hetényi G, Perga M-E, et al (2020) Designing inter- and transdisciplinary research on mountains: What place for the unexpected? Mt Res Dev 40(4):D10. https:// doi.org/10.1659/MRD-JOURNAL-D-20-00036.1

Patton AI, Rathburn SL, Capps DM (2019) Landslide response to climate change in permafrost regions. Geomorphology 340:116128. https://doi.org/10.1016/j.geomorph.2019.04.029

Patton MQ (2002) Two decades of developments in qualitative inquiry: a personal experiential perspective. Qual Soc Work 1(3):261-283. https://doi.org/10.1177/1473325002001003636

Peyaud V, Bouchayer C, Gagliardini O, Vincent C, Gillet-Chaulet F, et al (2020) Numerical modeling of the dynamics of Mer de Glace glacier, French Alps: Comparison with past observations and forecasting of near future evolution. Cryosphere Discuss 1-24. https:// doi.org/10.5194/tc-2020-75

Pohl B, Joly D, Pergaud J, Buoncristiani J-F, Soare P, et al (2019) Huge decrease of frost frequency in the Mont-Blanc Massif under climate change. Sci Rep 9(1):4919. https://doi.org/10.1038/ s41598-019-41398-5

Purdie H (2013) Glacier retreat and tourism: Insights from New Zealand. Mt Res Dev 33(4):463-472. https://doi.org/10.1659/MRDJOURNAL-D-12-00073.1

Purdie H, Gomez C, Espiner S (2015) Glacier recession and the changing rockfall hazard: Implications for glacier tourism. NZ Geogr 71(3):189-202. https://doi.org/10.1111/nzg.12091

Purdie H, Hutton JH, Stewart E, Espiner S (2020) Implications of a changing alpine environment for geotourism: A case study from Aoraki/Mount Cook, New Zealand. J Outdoor Recreat Tour 29:100235. https://doi.org/10.1016/j.jort.2019.100235

Ravanel L, Magnin F, Deline P (2017) Impacts of the 2003 and 2015 summer heatwaves on permafrost-affected rock-walls in the Mont Blanc massif. Sci Total Environ 609:132-143. https://doi.org/10. 1016/j.scitotenv.2017.07.055

Saillard EK (2011) Systematic versus interpretive analysis with two CAQDAS packages: NVivo and MAXQDA. Forum Qual Soz / Forum Qual Soc Res 12(1):1. https://doi.org/10.17169/fqs-12.1. 1518

Salim E (2020) Nouvelle Zélande: Le tourisme glaciaire face aux évolutions climatiques. J Alp Res I Revue de géographie alpine. http:// journals.openedition.org/rga/6824. Accessed 20 Oct 2021

Salim E, Ravanel L, Deline P, Gauchon C (2021a) A review of melting ice adaptation strategies in the glacier tourism context. Scand J Hosp Tour 21(2):229-246. https://doi.org/10.1080/15022250. 2021.1879670
Salim E, Gauchon C, Ravanel L (2021b) Seeing the ice. An overview of Alpine glacier tourism sites, between post- and hyper-modernity. J Alp Res I Revue de Géographie Alpine. http://journals.opene dition.org/rga/8383. Accessed 20 Oct 2021

Salim E, Ravanel L (2020) Last chance to see the ice: Visitor motivation at Montenvers-Mer-de-Glace. French Alps Tourism Geographies 107:1-23. https://doi.org/10.1080/14616688.2020.1833971

Savoie-Mont-Blanc Tourisme (2019) La fréquentation des sites, monuments et manufestations. Agence Savoie Mont Blanc, p 3. https:// pro.savoie-mont-blanc.com/var/ezwebin_site/storage/original/ application/bfdd22b973c7d0c367ed1fd3e6154e43.pdf. Accessed 20 Oct 2021

Scott D (2021) Sustainable tourism and the grand challenge of climate change. Sustainability 13(4):1966. https://doi.org/10.3390/su130 41966

Scott D, Hall CM, Gössling S (2019) Global tourism vulnerability to climate change. Ann Tour Res 77:49-61. https://doi.org/10.1016/j. annals.2019.05.007

Steiger R, Scott D, Abegg B, Pons M, Aall C (2019) A critical review of climate change risk for ski tourism. Curr Issue Tour 22(11):1343-1379. https://doi.org/10.1080/13683500.2017.14101 10

Stewart EJ, Wilson J, Espiner S, Purdie H, Lemieux C, et al (2016) Implications of climate change for glacier tourism. Tour Geogr 18(4):377-398. https://doi.org/10.1080/14616688.2016.1198416

Stoffel M, Tiranti D, Huggel C (2014) Climate change impacts on mass movements-Case studies from the European Alps. Sci Total Environ 493:1255-1266. https://doi.org/10.1016/j.scito tenv.2014.02.102

Tsutaki S, Nishimura D, Yoshizawa T, Sugiyama S (2011) Changes in glacier dynamics under the influence of proglacial lake formation in Rhonegletscher. Switzerland Annals of Glaciology 52(58):3136. https://doi.org/10.3189/172756411797252194

UNWTO and UNDP (2017) Tourism and the sustainable development goals - journey to 2030: Hightlights (UNWTO). https://www.eunwto.org/doi/pdf/10.18111/9789284419340. Accessed 20 Oct 2021

UNWTO, WMO, UNEP (eds) (2008) Climate change and tourism: responding to global challenges. World Tourism Organization

Vincent C, Meur EL, Six D, Thibert E (2007) Un service d'observation des glaciers des alpes françaises «glacioclim-alpes », pour quoi faire? La Houille Blanche 3:86-95. https://doi.org/10.1051/lhb: 2007040

Vincent C, Peyaud V, Laarman O, Six D, Gilbert A, et al (2019) Déclin des deux plus grands glaciers des Alpes françaises au cours du XXIe siècle: Argentière et Mer de Glace. La Météorologie 106:49. https://doi.org/10.4267/2042/70369

Wang S-J, Zhou L-Y (2019) Integrated impacts of climate change on glacier tourism. Adv Clim Chang Res 10(2):71-79. https://doi. org/10.1016/j.accre.2019.06.006

Watson CS, King O (2018) Everest's thinning glaciers: Implications for tourism and mountaineering. Geol Today 34(1):18-25. https:// doi.org/10.1111/gto.12215

Welling J, Abegg B (2019) Following the ice: Adaptation processes of glacier tour operators in Southeast Iceland. Int J Biometeorol. https://doi.org/10.1007/s00484-019-01779-x

Welling JT, Árnason P, Ólafsdottír R (2015) Glacier tourism: A scoping review. Tour Geogr 17(5):635-662. https://doi.org/10.1080/ 14616688.2015.1084529

Publisher's note Springer Nature remains neutral with regard to jurisdictional claims in published maps and institutional affiliations. 